\title{
Mitochondrial DNA reveals Pleistocenic colonisation of the Mediterranean by loggerhead turtles (Caretta caretta)
}

\author{
Marcel Clusa a,*, Carlos Carreras a , Marta Pascual ${ }^{\text {b }}$, Andreas Demetropoulos ${ }^{\text {c }}$, Dimitris Margaritoulis ${ }^{\mathrm{d}}$, \\ Alan F. Rees ${ }^{\mathrm{d}}$, Abdulmaula A. Hamza ${ }^{\mathrm{e}}$, Mona Khalil ${ }^{\mathrm{f}}$, Monica Aureggi ${ }^{\mathrm{g}}$, Yaniv Levy ${ }^{\mathrm{h}}$, Ogüz Türkozan ${ }^{\mathrm{i}}$, \\ Adolfo Marco ${ }^{\mathrm{j}}$, Alex Aguilar ${ }^{\mathrm{a}}$, Luis Cardona ${ }^{\mathrm{a}}$
}

a Department of Animal Biology and IRBio, Faculty of Biology, University of Barcelona, Av. Diagonal 643, E-08028 Barcelona, Spain

b Department of Genetics and IRBio, Faculty of Biology, University of Barcelona, Av. Diagonal 643, E-08028 Barcelona, Spain

c Cyprus Wildlife Society, Emmanuel Xanthou 11, P.O. Box 24281, 1703 Nicosia, Cyprus

d ARCHELON, the Sea Turtle Protection Society of Greece, Solomou 57, GR-10432 Athens, Greece

e Libyan Seaturtle Program, Environment General Authority, Alfateh University, P.O. Box 13793, Tripoli, Libya

f MEDASSET, P.O. Box 19, Tyre, Lebanon

${ }^{g}$ Naucrates, Via Corbetta 11, 22063 Cantù, CO, Italy

h The Israel Sea Turtle Rescue Centre, Nature Parks Authority, Mevoot Yam, Mikhmoret 40297, Israel

i Adnan Menderes University, Faculty of Science and Arts, Department of Biology, Aydin, Turkey

j Biological Station of Doñana-CSIC, Apdo. 1056, E-41013 Seville, Spain

Keywords:

Caretta caretta

Genetic structuring

Glacial refugia

Molecular clock

mtDNA

Phylogeography

\begin{abstract}
A B S T R A C T
As the loggerhead turtle (Caretta caretta) is a philopatric species with a strong genetic structure, the analysis of mtDNA can be used to track evolutionary and colonisation events. In this study we use a genetic approach to understand the population structure of $C$. caretta in the Mediterranean Sea and to test whether loggerheads could have colonised the Mediterranean during the Pleistocene and survived the cold phases in warm refugia. We amplified a long mtDNA D-loop fragment (815 bp) from 168 dead hatchlings sampled from a selection of rookeries in the Eastern Mediterranean: Libya, Israel, Lebanon, Cyprus and Greece. Previously published data from Turkey and Calabria (Southern Italy) were also included in the analyses. The population nesting in Libya emerged as the oldest population in the Mediterranean, dating from the Pleistocene ca. 65,000 years ago $(20,000-200,000)$. This reveals that the Libyan population might have settled in the Mediterranean basin before the end of the last glacial period. The remaining nesting sites, except Calabria, were subsequently colonised as the population expanded. The populations nesting in Eastern Turkey and Western Greece settled ca. 30,000 years ago $(10,000-100,000)$, whereas the remaining populations originated as a result of a more recent Holocenic expansion. As Calabria presented a unique Atlantic haplotype, found nowhere else in the Mediterranean, we consider this nesting site as the result of an independent colonisation event from the Atlantic and not the recent spread of Mediterranean populations. This reveals that the current genetic structure of $C$. caretta rookeries in the Mediterranean would be the result of at least two colonisation events from the Atlantic, the oldest one in Libya and a most recent in Calabria, combined with local extinctions during Pleistocenic glaciations and re-colonisations from glacial refugia in Libya, Eastern Turkey and Western Greece.
\end{abstract}

\section{Introduction}

The Pleistocene extended from 2.5 mya to 12 kya and was characterised by multiple glacial-interglacial cycles that caused dramatic changes in the distribution of organisms (Taberlet et al., 1998; Wilson and Eigenmann Veraguth, 2010). As ice sheets spread during glacial cycles, species often retreated towards the Equator although some

\footnotetext{
* Corresponding author at: Department of Animal Biology, Faculty of Biology, University of Barcelona, Av. Diagonal 643, E-08028 Barcelona, Spain. Tel.: + 34934035370. E-mail address: mclusa@ub.edu (M. Clusa).
}

populations survived in areas that acted as refugia (Haffer, 1982). Furthermore, a dryer climate and lower sea levels during glacial periods caused dramatic changes in species distribution even in areas that were not covered by ice (Hewitt, 1996; Maggs et al., 2008). When ice retreated due to post-glacial temperature rises, species re-expanded their distribution polewards, occupying previously inhospitable areas (Hewitt, 2000). These patterns are well established for terrestrial organisms, but the response to Pleistocenic glacial-interglacial cycles is still unclear for many marine species.

After the Messinian Salinity Crisis (5.33-5.59 mya), the Mediterranean basin was colonised by subtropical biota of Atlantic origin 
(Pérès, 1985). During the following climatic fluctuations, species distributions were affected by changes in the sea level, water temperature and salinity (Grant and Bowen, 1998). According to the fossil records, the most thermophilic groups became extinct during the first cold period of the Pleistocene and waves of extinction and invasion changed the composition of the Mediterranean biota in every climatic phase (Pérès, 1985). Nevertheless, recent molecular evidence has suggested that at least some of the subtropical species currently found in the Mediterranean are not recent Holocenic invaders, but have a pre-glacial origin and survived the glacial peaks in warmer refugia within the Mediterranean (Almada et al., 2001; Domingues et al., 2007; Wilson and Eigenmann Veraguth, 2010). Molecular data indicate that the southern parts of the Mediterranean, being warmer than northern areas during the Pleistocene (Thiede, 1978), acted as refugia for sea grasses (e.g. Posidonia oceanica, Arnaud-Haond et al., 2007; Cymodocea nodosa, Alberto et al., 2008) and that the Ionian and Aegean Sea, acted in the same way for some fish species (BahriSfar et al., 2000; Magoulas et al., 1996).

Marine turtles have tropical affinities and females are highly philopatric, returning to specific geographical locations to nest (Carr and Ogren, 1960; FitzSimmons et al., 1997; Meylan et al., 1990). This results in strong genetic structuring when mtDNA is considered (Bowen and Karl, 2007; Lee, 2008), allowing evolutionary and colonisation events to be traced (Garofalo et al., 2009). The loggerhead turtle (Caretta caretta L.) is the least thermophilic cheloniid and regularly nests in subtropical and warm temperate regions where sand temperature is higher than $24{ }^{\circ} \mathrm{C}$ for a sufficiently long period of time (Miller et al., 2003). Paleoclimatic reconstructions of sea surface temperatures indicate that loggerhead turtles could not use the Western Mediterranean even as a foraging ground due to low sea surface temperatures during the last glacial peak (summer surface temperature $<17^{\circ} \mathrm{C}$; Thiede, 1978). Only the Eastern Mediterranean was warm enough to allow turtle nesting, as summer sea surface temperatures were usually higher than $22{ }^{\circ} \mathrm{C}$ (Thiede, 1978); the minimum threshold for loggerhead turtle nesting (Miller et al., 2003). Thus, in the case that $C$. caretta had already colonised the Mediterranean prior to glaciation events, these Eastern regions could have acted as refugia for loggerhead turtles through the cold phases of the Pleistocene. Nevertheless, Bowen et al. (1993a) proposed a recent Holocenic origin for loggerhead turtles currently nesting in the Mediterranean. However, their conclusion was based on the analysis of just one nesting ground from the Ionian Sea (Bay of Kyparissia), the only rookery sampled at that time. New genetic data on the Mediterranean populations have come to light since (Carreras et al., 2007; Chaieb et al., 2010; Encalada et al., 1998; Garofalo et al., 2009; Laurent et al., 1998; Saied et al., 2012; Yilmaz et al., 2011).

To track the colonisation history of the Mediterranean by loggerhead turtles and to test the possible existence of warm refugia during the cold phases we have analysed mtDNA sequences from multiple nesting grounds in the Eastern Mediterranean, including previously poorly sampled locations.

\section{Material and methods}

\subsection{Sample collection}

Samples of skin and/or muscle were taken from 168 dead hatchlings and embryos from unhatched eggs during post-hatch nest excavations of nesting grounds in the Mediterranean Sea between 2003 and 2006 (Fig. 1, Table 1). These included Libya (west of Sirte), Israel (scattered sites along the whole coastline), Lebanon (El Mansouri), Cyprus (Alagadi and Akamas) and Greece, with samples from Western Greece (Zakynthos and Lakonikos Bay) and Crete (Rethymno). Samples were stored in 95\% ethanol and samples from Greece, Israel and Lebanon previously analysed by Carreras et al. (2007) were also used for this study. Independency among samples can be assumed because sampling included protocols to avoid pseudoreplication. These included female tagging and samples taken from clutches laid within a 15-day window to avoid hatchlings from the same individual turtle, as females rarely nest at intervals shorter than this period (Dutton, 1995). However, the new samples from Lebanon were collected in different years from those from Carreras et al. (2007) and hence, additional pseudoreplication tests were undertaken to ensure independency between samples. Pseudoreplication was assessed by amplifying the new samples with seven microsatellite loci (Carreras et al., 2007) and comparing them with the Lebanon samples in Carreras et al. (2007). A pairwise relatedness analysis implemented in GenAlEx v6.4 (Peakall and Smouse, 2006) was used for the comparison.

\subsection{DNA extraction and amplification}

DNA was extracted with the QIAamp extraction kit (QIAGEN®) and an 815 bp fragment of the mtDNA control region was amplified by polymerase chain reaction (PCR) using the primer pair LCM15382 (5'-GCTTAACCCTAAAGCATTGG-3') and H950 (5'-GTCTCGGATTTAGGG GTTT-3') (Abreu-Grobois et al., 2006). The analysis of longer sequences has been proven to improve the genetic resolution in $C$. caretta populations (Monzón-Argüello et al., 2010; Saied et al., 2012). The resulting fragment contains the $380 \mathrm{bp}$ fragment traditionally used for population studies on this species (Carreras et al., 2006; Encalada et al., 1998; Norman et al., 1994). PCR cycling parameters were $94{ }^{\circ} \mathrm{C}$ for $5 \mathrm{~min}$ followed by 35 cycles at $94{ }^{\circ} \mathrm{C}$ for $1 \mathrm{~min}, 52{ }^{\circ} \mathrm{C}$ for $1 \mathrm{~min}$, and $72{ }^{\circ} \mathrm{C}$ for $90 \mathrm{~s}$, and a final extension period of $72{ }^{\circ} \mathrm{C}$ for $10 \mathrm{~min}$. Resulting products were purified by enzymatic reaction (ExoSAP) and sequencing reactions undertaken with fluorescent dye terminators (BigDye v3.1®). All samples were sequenced in both forward and reverse directions on an ABI 3730 automated DNA Analyser (Applied Biosystems $\left.{ }^{\circledR}\right)$ to confirm variable sites on both strands of DNA.

\subsection{Data analysis}

Alignment was conducted using BioEdit v5.0.9 (Hall, 1999) and sequences were compared to short and long haplotypes previously described for this species and compiled by the Archie Carr Center for Sea Turtle Research of the University of Florida (ACCSTR; http:// accstr.ufl.edu). New haplotypes identified were named following ACCSTR standardised nomenclature and submitted to GenBank (Accession nos. JF837821-JF837824).

To understand the genetic relationships between the sampled rookeries, pairwise genetic distances $\left(\gamma_{s t}\right)$ were calculated by the DnaSP v5 software package (Librado and Rozas, 2009). The significance of genetic differentiation among these regions was assessed using Hudson's nearest neighbour statistics $\left(\mathrm{S}_{\mathrm{NN}}\right)$ with 1000 permutations in DnaSP. Published long sequence data from Southern Italy (Calabria; Garofalo et al., 2009) and Turkey (Yilmaz et al., 2011, which includes Turkish samples from Carreras et al., 2007) were also used in the analyses. Five nesting groups were considered in Turkey as suggested by the authors' conclusions (Yilmaz et al., 2011): Dalyan, Dalaman, Western Turkey (Fethiye, Patara, Kale, Kumluca and Çirali), middle Turkey (Gazipaşa, Kizilot, Tekirova and Belek) and Eastern Turkey (Anamur, Göksu Deltasi, Alata, Kazanli, Akyatan, Ağyatan and Samandağ). Recently published data from Libya (Saied et al., 2012) were not added to our dataset to avoid pseudoreplication as samples from both datasets were collected from the same location (Sirte) within a three year window. However, genetic differentiation analyses were undertaken with both datasets separately to look for possible differences. Following Narum (2006), modified false discovery rate (FDR) was used to evaluate statistical significance instead of the sequential Bonferroni correction when analysing multiple comparisons. Haplotype diversity ( $h$; Nei, 1987) and nucleotide diversity ( $\pi$; Nei, 1987) were estimated using ARLEQUIN v3.1 (Excoffier et al., 2005) and Fu's Fs values for each nesting region were calculated with DnaSP. 


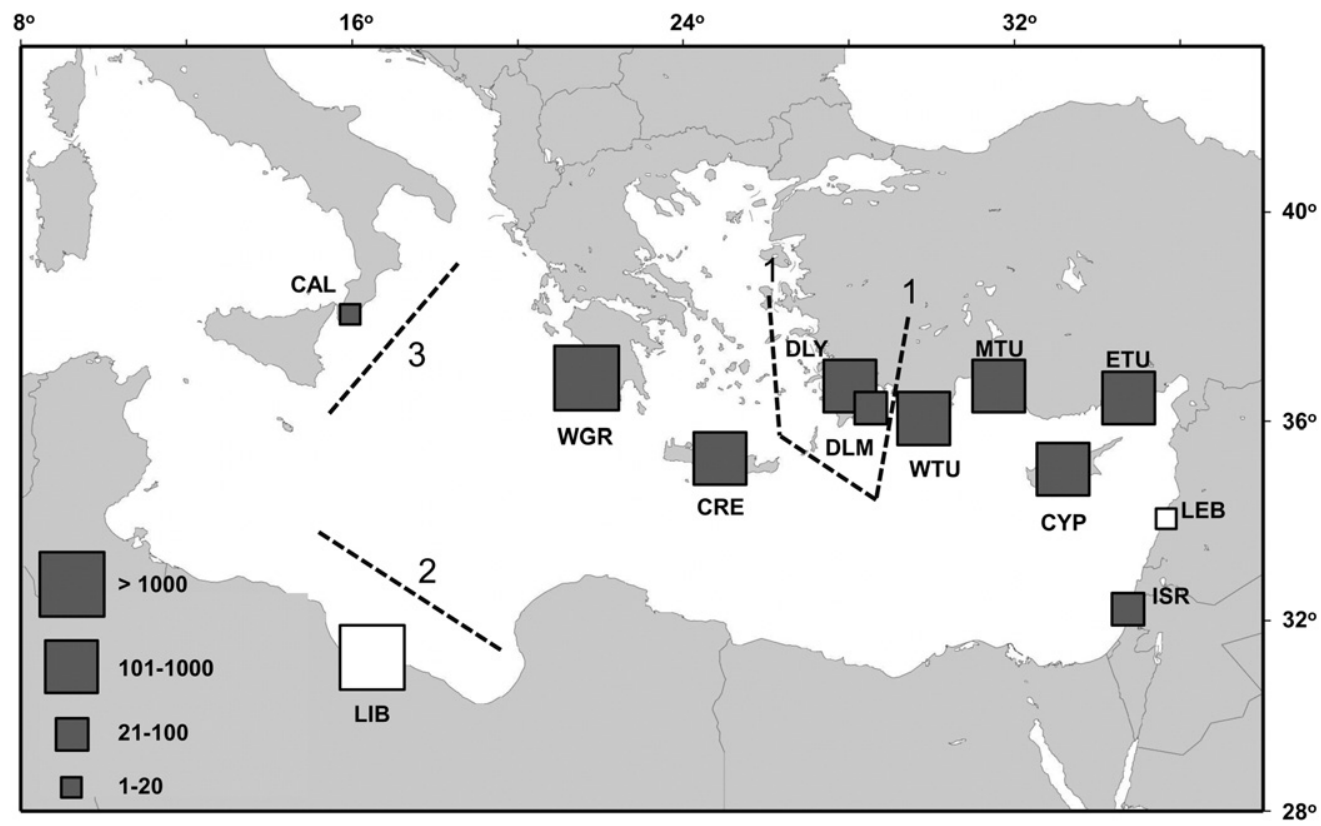

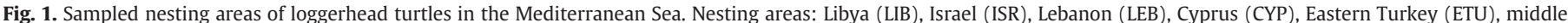

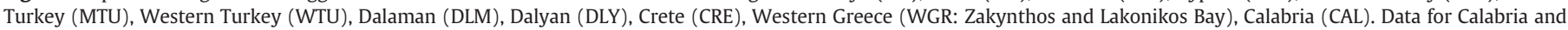

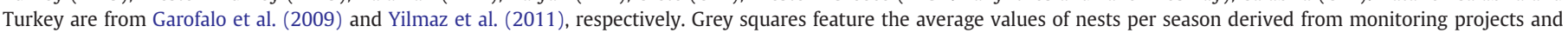

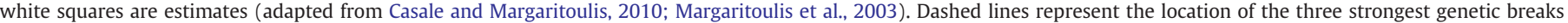
revealed by BARRIER. The lowest number indentifies the strongest barrier.

Fs detects deviation from neutrality and tends to be negative under an excess of recent mutations (Fu, 1997), which can result from population expansion. A partial correlation test between nucleotide diversity, mean width of the continental shelf (calculated with the ArcGIS software; ESRI, 2011) and the sea surface palaeotemperature (Thiede, 1978) in each nesting area was also carried out with SPSS v15 (SPSS Inc., 2006). The test was used to relate genetic diversities with environmental factors that could have affected nesting patterns. When necessary, variables were log-transformed or arcsine-transformed to satisfy the normality criterion (Zar, 1984).

Genetic structuring on a geographical scale was analysed with a Mantel test using genepop v 4.1 (Rousset, 2008). This analysis was conducted with minimum linear (Lat/Long positions) and coastal distances (following the coastline) between locations, calculated using the ArcGIS software (ESRI, 2011). Subsequently, based on a $\gamma_{s t}$ distance matrix, BARRIER v 2.2 (Manni et al., 2004) was used to assess the relative order of importance of genetic breaks that could limit gene flow between populations. Previous studies based on mtDNA and microsatellite markers suggested that four is the most likely number of populations present in the Eastern Mediterranean (Carreras et al., 2007), which would imply the existence of three putative barriers. In consequence, we chose a priori to show four barriers since we used additional populations. In order to assess the proportion of genetic variation that explained the differences among nesting grounds, an analysis of molecular variance (AMOVA) was undertaken with ARLEQUIN considering the four groups identified by the three strongest barriers.

To graphically relate pairwise genetic distances $\left(\gamma_{\mathrm{st}}\right)$ between areas, a Principal Coordinate Analysis (PCA) was performed with GenAlEx v6.4 (Peakall and Smouse, 2006). Relationships between haplotypes were obtained by the calculation of a haplotype network with the network v4.5.1.6 software (Bandelt et al., 1999) using a Median Joining method. Less likely events were weighted differently from likely events, changing deletion (double weight) and transversion weights $(3 \times)$ according to user guidelines.
Finally, a molecular clock was applied to date the different colonisation events, using two different approaches. In the first one, the substitution rate for the 815 bp mtDNA fragment was calibrated assuming that the divergence between the two major branches of the Atlantic/Mediterranean haplotype tree occurred as a consequence of the rise of the Isthmus of Panama (Bowen, 2003). The Isthmus started rising 15 mya and did not become a complete marine barrier until ca. 3 mya (Lessios, 2008). Consequently, we rooted our molecular clock at 3 mya for conservative purposes. The substitution rate was obtained following the methodology previously used for testudines by Avise et al. (1992) considering the 39 fixed mutations existing between the closest related haplotypes (CC-A1.6 and CC-A31.1) of the two major branches of the Atlantic/Mediterranean haplotype tree resulting in a substitution rate of $\sim 0.8 \% \mathrm{My}^{-1}$. However, it has been recently pointed out that the molecular evolutionary rate of mitochondrial DNA may be time-dependent (Crandall et al., 2012; Ho et al., 2011; Karl et al., 2012). Consequently, the substitution rate likely overestimates divergence times (Crandall et al., 2012), as calibration was done with an old event ( 3 mya). No recent calibration points or well-known pedigrees exist to estimate accurate divergence rates for this species. Thus, a second, more conservative approach using the mutation rate to date haplotype coalescence times was used following Emerson (2007). The mutation rate has been described to be 3-10 times faster than the substitution rate in other species (Howell et al., 2003; Lambert et al., 2002). In addition, the mean rate of change for mtDNA genes in three marine invertebrate species calibrated with radiometric dates for sea-level rise yielded values 3 times faster than those estimated from fossils and vicariant events (Crandall et al., 2012). Thus, we estimated the divergence time between haplotypes of $C$. caretta using a mutation rate three times faster than the substitution rate and obtained lower and upper estimates by also dating coalescence times using the substitution rate and a mutation rate ten times faster than the substitution rate. A Bayesian relaxed-clock model was subsequently applied as implemented in beast v1.6.2 (Drummond and Rambaut, 2007). Four unique Atlantic haplotypes (CC-A1.1, CC-A1.3, CC-A1.4 and CC-A1.6), 


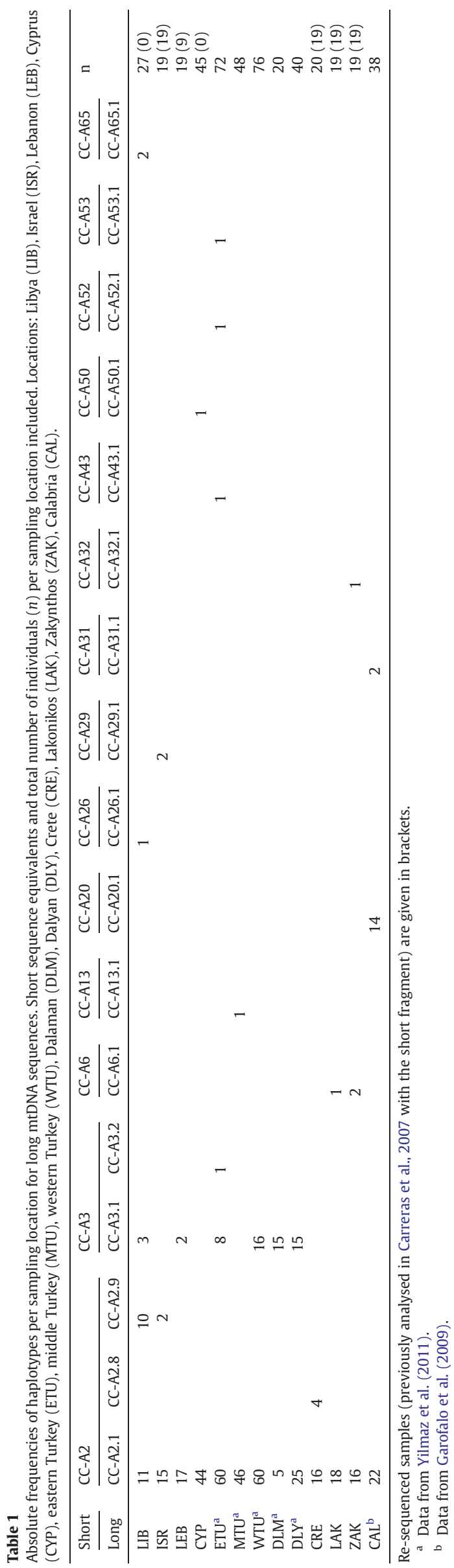

were chosen as outgroups to root our Mediterranean haplotype tree. Markov-Chain Monte Carlo (MCMC) simulations were run for $10,000,000$ generations, with the first $10 \%$ discarded as burn-in.

\section{Results}

A total of 17 haplotypes were found among the analysed Mediterranean rookeries (Table 1). In Lebanon, the comparison of the microsatellite genotypes (data not shown) of the new and old samples from Carreras et al. (2007) indicated that pseudoreplication did not occur in this population (mean LRM $=-0.062 \pm 0.110$ ). Thus, all samples from Lebanon rookeries were pooled for further analyses. Most long haplotypes found in the current study were concurrent with the short ones previously described for the Mediterranean Sea (Carreras et al., 2007; Encalada et al., 1998; Laurent et al., 1998), as the new fragments include the old $380 \mathrm{bp}$ fragments (AbreuGrobois et al., 2006). However, some haplotypes identified with the 380 bp sequence were split into additional haplotypes, due to further polymorphism in the additional fragment of the longer sequences (e.g. Table 1; CC-A2 split into CC-A2.1, CC-A2.8, CC-A2.9). Three new haplotypes were described because of an increase in sequence length that could be directly related to the 380 bp haplotypes: CC-A29.1 in Israel, CC-A32.1 in Zakynthos and CC-A50.1 in Cyprus (Table 1; GenBank accession nos. JF837821-JF837823). Furthermore, a new haplotype, not previously described for either long or short sequences, was found in Libya (CC-A65.1; GenBank accession no. JF837824); an unsampled or low sampled region in previous studies with short sequences (Carreras et al., 2007; Encalada et al., 1998; Laurent et al., 1993, 1998; but see Saied et al., 2012).

CC-A2.1 was the most frequent haplotype in the dataset (77.33\%), followed by CC-A3.1 (12.50\%). Of the remaining haplotypes, 13 were unique to a specific nesting beach and two were shared between Mediterranean nesting sites, although they did not occur at high frequencies. The haplotype network showed a divergent sub-group with two unique haplotypes in Libya (CC-A26.1 and CC-A65.1) and one haplotype also shared with Israel (CC-A2.9) (Fig. 2). Eastern Turkey also presented a sub-group with unique related haplotypes (CC-A3.2 and CC-A52.1). However, Eastern Turkey's unique haplotypes had fewer mutation changes from the ancestral haplotype (CC-A2.1) than haplotypes from Libya. An ambiguity in the haplotype tree was found (am, Fig. 2) between CC-A3.1 and the unshared haplotypes from Western Greece (CC-A6.1 and CC-A32.1). It was resolved as indicated by Carreras et al. (2007) for short fragments based on geographical location similarities, as CC-A32.1 is only present in Western Greece and CC-A3.1 has not been found on these rookeries. On the other hand, CC-A32.1 and CC-A6.1 share a gap but differ by a transition whilst CC-A32.1 and CC-A3.1 differ by that gap but share the transition. Thus, the most parsimonious explanation to this ambiguity is that the transition independently arose twice, as previously suggested (Carreras et al., 2007).

Haplotype ( $h=0.04-0.70)$ and nucleotide $(\pi=0.000-0.002)$ diversities were highly variable (Table 2 ) due to the high number of haplotypes present in Eastern Turkey, Western Greece, Libya and Calabria in comparison to Cyprus, where very low variability was detected. Significant pairwise genetic differences were found in the majority of comparisons including Libya, Calabria and Dalaman (Table 3), thus revealing genetic structure within the basin (Global $\gamma_{s t}=0.262$, $\mathrm{P}<0.001$ ). Global $\gamma_{s t}$ values of all the Mediterranean rookeries did not differ when changing our dataset from Libya with the data from Saied et al. (2012) (Global $\left.\gamma_{s t}=0.264, \mathrm{P}<0.001\right)$. Furthermore, the two sets from Libya did not differ statistically $\left(\gamma_{s t}=0.001, P=0.215\right)$ despite some unshared haplotypes. Thus, both datasets agree in identifying Libya as the most diverse nesting area in the Mediterranean (Table 2).

Due to the lack of statistically significant divergence between Lakonikos and Zakynthos $\left(\gamma_{s t}=0.027, P=0.99\right)$ they were considered as subsamples of the same population, pooled for further analyses and 


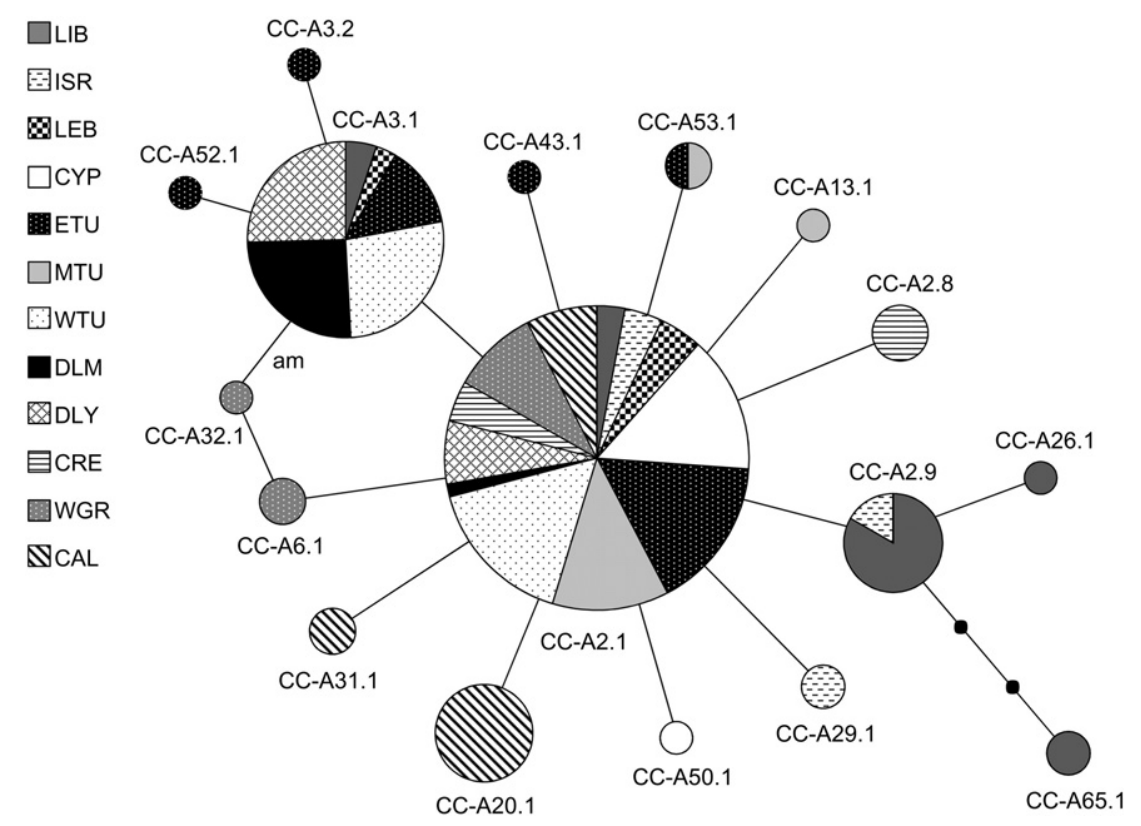

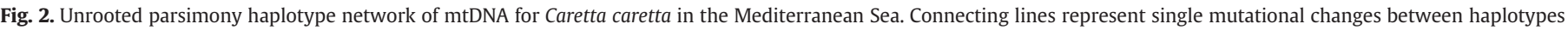

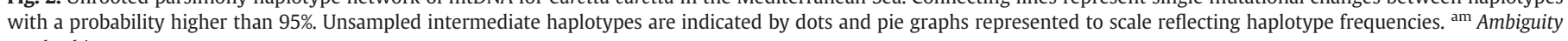
resolved in text.

referred to as Western Greece (WGR). This grouping was supported by the presence of the unique CC-A6.1 haplotype in both nesting areas and the evidence of female exchanges between Aegean Greece and the Ionian islands found in previous tagging studies (Margaritoulis, 1998) and microsatellite analyses (Carreras et al., 2007).

The global Fu's Fs test $(F s=-15.459, \mathrm{P}<0.01)$ was significant, indicating deviation from neutrality and a possible recent population expansion in this area, although for each location separately only Eastern Turkey presented a significantly negative Fu's $F s$ value $(F s=-4.119$, $\mathrm{P}<0.01$; Table 2). The arcsine-transformed nucleotide diversity estimates were strongly correlated (partial correlation $\mathrm{r}=0.847, \mathrm{P}=$ 0.002 ) with the log-transformed mean width of the continental shelf and the sea surface temperature values during the last glacial period.

Geographic and genetic distances were uncorrelated both when using Lat/Long positions (Mantel test, $\mathrm{P}=0.160$ ) and minimum coastal distances (Mantel test, $\mathrm{P}=0.165$ ). BARRIER indicated that the strongest genetic barrier detected by the Monmonier's maximum difference algorithm (Fig. 1) was found between Dalaman and Dalyan

\section{Table 2}

Haplotype and nucleotide diversities including standard deviations $( \pm)$, results of Fu's Fs test and sample sizes per sampling location. The latitude (Lat.) and longitude (Long.) positions refer to a central point per nesting area, not to the specific position of the beach sampled, as samples came from wide areas pooled under one single location. Population abbreviations as in Table 1. Western Greece (WGR) groups individuals from LAK and ZAK.

\begin{tabular}{lllllll}
\hline & $\begin{array}{l}\text { Haplotype } \\
\text { diversity }\end{array}$ & $\begin{array}{l}\text { Nucleotide } \\
\text { diversity }\end{array}$ & Fu's Fs & $\mathrm{n}$ & Lat. & Long. \\
\hline LIB & $0.704 \pm 0.054$ & $0.0017 \pm 0.0012$ & -0.909 & 27 & $30^{\circ} 59^{\prime} 19^{\prime \prime} \mathrm{N}$ & $17^{\circ} 34^{\prime} 50^{\prime \prime} \mathrm{E}$ \\
ISR & $0.374 \pm 0.130$ & $0.0005 \pm 0.0005$ & -0.671 & 19 & $32^{\circ} 02^{\prime} 37^{\prime \prime} \mathrm{N}$ & $34^{\circ} 44^{\prime} 45^{\prime \prime} \mathrm{E}$ \\
LEB & $0.199 \pm 0.112$ & $0.0002 \pm 0.0004$ & -0.055 & 19 & $33^{\circ} 16^{\prime} 32^{\prime \prime} \mathrm{N}$ & $35^{\circ} 11^{\prime} 33^{\prime \prime} \mathrm{E}$ \\
CYP & $0.044 \pm 0.042$ & $0.0001 \pm 0.0002$ & -1.548 & 45 & $35^{\circ} 04^{\prime} 09^{\prime \prime} \mathrm{N}$ & $33^{\circ} 19^{\prime} 33^{\prime \prime} \mathrm{E}$ \\
ETU & $0.297 \pm 0.067$ & $0.0004 \pm 0.0005$ & $-\mathbf{4 . 1 1 9}$ & 72 & $36^{\circ} 45^{\prime} 50^{\prime \prime} \mathrm{N}$ & $34^{\circ} 52^{\prime} 37^{\prime \prime} \mathrm{E}$ \\
MTU & $0.082 \pm 0.054$ & $0.0001 \pm 0.0002$ & -2.976 & 48 & $36^{\circ} 42^{\prime} 24^{\prime \prime} \mathrm{N}$ & $31^{\circ} 34^{\prime} 16^{\prime \prime} \mathrm{E}$ \\
WTU & $0.337 \pm 0.054$ & $0.0004 \pm 0.0005$ & 1.338 & 76 & $36^{\circ} 12^{\prime} 31^{\prime \prime} \mathrm{N}$ & $29^{\circ} 34^{\prime} 17^{\prime \prime} \mathrm{E}$ \\
DLM & $0.395 \pm 0.101$ & $0.0005 \pm 0.005$ & 0.976 & 20 & $36^{\circ} 41^{\prime} 51^{\prime \prime} \mathrm{N}$ & $28^{\circ} 45^{\prime} 33^{\prime \prime} \mathrm{E}$ \\
DLY & $0.481 \pm 0.042$ & $0.0006 \pm 0.0006$ & 1.728 & 40 & $36^{\circ} 47^{\prime} 28^{\prime \prime} \mathrm{N}$ & $28^{\circ} 37^{\prime} 16^{\prime \prime} \mathrm{E}$ \\
CRE & $0.337 \pm 0.110$ & $0.0004 \pm 0.0005$ & 0.721 & 20 & $35^{\circ} 21^{\prime} 51^{\prime \prime} \mathrm{N}$ & $24^{\circ} 27^{\prime} 29^{\prime \prime} \mathrm{E}$ \\
WGR & $0.198 \pm 0.083$ & $0.0003 \pm 0.0004$ & -1.407 & 38 & $35^{\circ} 59^{\prime} 00^{\prime \prime} \mathrm{N}$ & $21^{\circ} 39^{\prime} 15^{\prime \prime} \mathrm{E}$ \\
CAL & $0.541 \pm 0.049$ & $0.0007 \pm 0.0007$ & 0.522 & 38 & $37^{\circ} 55^{\prime} 06^{\prime \prime} \mathrm{N}$ & $15^{\circ} 58^{\prime} 45^{\prime \prime} \mathrm{E}$ \\
\hline
\end{tabular}

In bold significant values (Fu's Fs, $\mathrm{P}<0.01$ ). and the remaining populations (Barrier $1, \gamma_{s t}=0.582$ ). The second barrier separated Libya (Barrier 2, $\gamma_{s t}=0.227$ ) and the third, Calabria from the rest (Barrier 3, $\gamma_{s t}=0.184$ ). The fourth was found between Dalaman and Dalyan (Barrier 4, $\gamma_{s t}=0.125$ ). The four groups (Libya, Dalaman and Dalyan, Calabria and the rest of the populations) identified by the three strongest barriers (Fig. 1) were subsequently used for the AMOVA analysis (Table 4). Under this analysis, the highest percentage of variation was found within populations (66.57\%) although the percentage of variation between groups was also significant and high (28.68\%). PCA based on genetic distances $\left(\gamma_{s t}\right)$ between locations (Table 3) identified Dalaman, Dalyan, Libya and Calabria as highly distinct rookeries, with too small an amount of differentiation among the remaining rookeries to be classified as separate units (Fig. 3).

Finally, based on the haplotype network and the number of mutations between haplotypes, a molecular clock was applied to date haplotype divergences. Dates were estimated with a mutation rate three times faster than the substitution rate. We used the inferred substitution rate calculated for this species $\left(\sim 0.8 \% \mathrm{My}^{-1}\right)$ as a lower bound and a mutation rate 10 times faster than the substitution rate as an upper bound. Haplotype CC-A65.1 (exclusive to Libya), with four changes from the ancestral CC-A2.1, revealed Libya as the oldest population while haplotypes CC-A32.1 (exclusive to Western Greece) and CC-A3.2 and CC-A52.1 (exclusive to Eastern Turkey), with two changes from the Atlantic ancestor, suggested that these areas would have been more recent. Thus, Libya could have been colonised ca. 65,000 years ago (20,000-200,000) and Western Greece and Eastern Turkey ca. 30,000 years ago $(10,000-100,000)$. The remaining populations originated as a result of a more recent, Holocenic expansion. All results were supported by the relaxed-clock model tree implemented in beast (Fig. 4), with haplotypes unique to Libya, Eastern Turkey and Western Greece diverging before the rest, thus revealing these as the oldest populations of the Mediterranean.

\section{Discussion}

The study of molecular genetic differentiation between populations of endangered species has been described as a powerful tool for conservation planning (Crandall et al., 2000; Moritz, 1994). However, the markers selected and the length of the DNA sequences analysed can 
Table 3

Pairwise genetic distances between Mediterranean nesting populations $\left(\gamma_{\mathrm{st}}\right)$ (below diagonal) and $\mathrm{S}_{\mathrm{NN}}$ significance (P) values (above diagonal).

\begin{tabular}{|c|c|c|c|c|c|c|c|c|c|c|c|c|}
\hline & LIB & ISR & LEB & CYP & ETU & MTU & WTU & DLM & DLY & CRE & WGR & CAL \\
\hline LIB & - & 0.001 & $\sim 0.000$ & $\sim 0.000$ & $\sim 0.000$ & $\sim 0.000$ & $\sim 0.000$ & $\sim 0.000$ & $\sim 0.000$ & $\sim 0.000$ & $\sim 0.000$ & $\sim 0.000$ \\
\hline ISR & 0.108 & - & 0.083 & $\sim 0.000$ & 0.001 & 0.006 & $\sim 0.000$ & $\sim 0.000$ & $\sim 0.000$ & 0.024 & 0.011 & $\sim 0.000$ \\
\hline LEB & 0.160 & 0.056 & - & 0.087 & 0.913 & 0.061 & 0.329 & $\sim 0.000$ & 0.033 & 0.046 & 0.538 & $\sim 0.000$ \\
\hline CYP & 0.243 & 0.062 & 0.053 & - & 0.006 & 0.873 & $\sim 0.000$ & $\sim 0.000$ & $\sim 0.000$ & 0.007 & 0.718 & $\sim 0.000$ \\
\hline ETU & 0.160 & 0.038 & 0.002 & 0.040 & - & 0.039 & 0.189 & $\sim 0.000$ & 0.003 & 0.001 & 0.136 & 0.001 \\
\hline MTU & 0.235 & 0.054 & 0.042 & 0.011 & 0.039 & - & $\sim 0.000$ & $\sim 0.000$ & $\sim 0.000$ & 0.003 & 0.690 & $\sim 0.000$ \\
\hline WTU & 0.166 & 0.059 & 0.012 & 0.085 & 0.009 & 0.084 & - & $\sim 0.000$ & 0.075 & $\sim 0.000$ & 0.007 & $\sim 0.000$ \\
\hline DLM & 0.318 & 0.437 & 0.422 & 0.622 & 0.264 & 0.582 & 0.220 & - & $\sim 0.000$ & $\sim 0.000$ & $\sim 0.000$ & $\sim 0.000$ \\
\hline DLY & 0.187 & 0.139 & 0.077 & 0.224 & 0.062 & 0.214 & 0.031 & 0.125 & - & $\sim 0.000$ & $\sim 0.000$ & $\sim 0.000$ \\
\hline CRE & 0.178 & 0.082 & 0.091 & 0.118 & 0.056 & 0.101 & 0.078 & 0.464 & 0.161 & - & 0.010 & $\sim 0.000$ \\
\hline WGR & 0.227 & 0.060 & 0.028 & 0.012 & 0.024 & 0.011 & 0.059 & 0.592 & 0.186 & 0.113 & - & $\sim 0.000$ \\
\hline CAL & 0.211 & 0.124 & 0.131 & 0.196 & 0.145 & 0.189 & 0.165 & 0.388 & 0.213 & 0.144 & 0.184 & - \\
\hline
\end{tabular}

Bold values were significant after FDR correction for a threshold of $\alpha=0.05\left(\mathrm{~S}_{\mathrm{NN}}, \mathrm{P}<0.0105\right)$.

significantly alter the results (Monzón-Argüello et al., 2010; this study). For loggerhead turtles, the existence of genetic structure within the Mediterranean was previously detected with short sequences (380 bp) of the mtDNA control region (Carreras et al., 2007; Chaieb et al., 2010; Encalada et al., 1998; Laurent et al., 1998). Nonetheless, the higher nucleotide diversity present in the longer mtDNA fragment ( $815 \mathrm{bp}$ ), along with the analysis of individuals from previously poorly sampled populations, allowed us to unveil a deeper structuring within the Mediterranean Sea.

\subsection{Genetic structuring}

The use of longer sequences allowed the splitting of the short CC-A2 and CC-A3 haplotypes into long haplotypes (CC-A2.1, CC-A2.8, CC-A2.9 and CC-A3.1 and CC-A3.2), which in turn revealed further structuring within Crete and Israel (CC-A2.8, CC-A2.9) and Eastern Turkey (CC-A3.2). Furthermore, the inclusion of Calabria (Garofalo et al., 2009) and Libya in the analyses revealed high levels of structuring previously undescribed (Bowen et al., 1993a; Carreras et al., 2007), as these two regions emerged as the most genetically diverse. This is because of the presence of two unique haplotypes in each of the two regions (CC-A26.1 and CC-A65.1 in Libya, and CC-A20.1 and CC-A31.1 in Calabria) and also because of a higher degree of divergence between these haplotypes and the other Mediterranean haplotypes. However, even though Libya and Calabria were found to be the rookeries with the highest diversity indexes, PCA and BARRIER analyses identified Dalaman and Dalyan as a higher differentiated unit. This is because of the high occurrence of CC-A3.1 in these two regions and in particular in Dalaman, where the proportion of CC-A3.1 was even higher than that of CC-A2.1 (Yilmaz et al., 2011), something not observed in any other rookery of the basin. The nesting area of Eastern Turkey hosted three unique haplotypes (CC-A3.2, CC-A43.1 and CC-A52.1) and one only shared with middle Turkey (CC-A53.1). Nonetheless, their frequencies were remarkably low and thus Eastern Turkey did not emerge as a major genetic unit. Cyprus was confirmed as a region with low genetic variability despite the large increase in sample size in relation to previous studies (Carreras et al., 2007; Encalada et al., 1998). However, could be slightly differentiated from most of the other nesting areas by the overwhelming dominance of the CC-A2.1 haplotype. In conclusion, we identify four major clusters of nesting grounds: Libya, Dalaman and

Table 4

Analysis of molecular variance (AMOVA) for four Mediterranean genetic groups (Libya, Dalaman and Dalyan, Calabria and the rest of the sampled Mediterranean rookeries) based on the main three breaks inferred by BARRIER.

\begin{tabular}{lrlll}
\hline Source of variation & d.f. & Percentage of variation & F-statistic & P \\
\hline Among groups & 3 & 28.68 & FCT: 0.28681 & $<0.005$ \\
$\begin{array}{c}\text { Among populations } \\
\text { within groups }\end{array}$ & 8 & 4.74 & FSC: 0.06653 & $\sim 0.000$ \\
$\begin{array}{l}\text { Within populations } \\
4\end{array}$ & 450 & 66.57 & FST: 0.33426 & $\sim 0.000$ \\
\hline
\end{tabular}

Dalyan, Calabria and the rest of the Eastern Mediterranean, although some genetic differentiation exists within the latter cluster (Table 3).

\subsection{Evolutionary history}

The short (380 bp) haplotypes CC-A2, CC-A3 and CC-A20 are shared by Mediterranean and Atlantic rookeries (Bowen et al., 2004; Carreras et al., 2007; Garofalo et al., 2009; Monzón-Argüello et al., 2010; Shamblin et al., 2011), indicating that this could have probably been the minimal ancestral haplotypic composition of the stock of loggerhead turtles that colonised the Mediterranean from the Northern Atlantic. Nevertheless, Carreras et al. (2007) also suggested an alternative hypothesis in which the origin of CC-A3 in the Mediterranean could have been independent from the Atlantic, in a clear case of homoplasy. Only a future long sequence screening of the variants of the CC-A3 and CC-A20 short haplotypes present in the Atlantic nesting beaches will clarify which hypothesis is correct. Nevertheless, at least two different CC-A3 variants have already been detected in the Mediterranean (Table 1 from Yilmaz et al., 2011).

Regarding the species history within the Mediterranean Sea, the analysis of individuals from previously poorly sampled nesting grounds (Libya, Turkey) revealed an earlier colonisation of the basin than previously suggested (Bowen et al., 1993a). This dating relies not only on the new haplotypes found in these nesting grounds, but also on the divergence rates applied. The substitution rate estimated $\left(\sim 0.8 \% \mathrm{My}^{-1}\right)$ is higher than previously published estimates for other testudines $(0.2$ to $0.4 \%$, Avise et al., 1992; Bowen et al., 1993b) probably due to the use of different markers and the length of the sequences analysed. Bowen et al. (1993b) analysed the cytochrome b region, which presents a lower substitution rate than the control region of the mtDNA (Dutton et al., 1996). Furthermore, differences in nucleotide diversity along the control region can alter the estimates depending on the length and region sequenced (Monzón-Argüello et al., 2010). As a consequence, the long sequences of the control region presented here had higher nucleotide diversity than the shorter fragments and thus, the substitution rate estimated in the present study is higher. Nevertheless, this makes our estimates of the substitution rate among Mediterranean haplotypes more conservative and thus, the older coalescence times inferred are solely due to the presence of previously unsampled haplotypes from Libya and Turkey. The time estimates changed when using mutation rates 3 and 10 times higher than the phylogeographically calibrated substitution rate (Crandall et al., 2012; Emerson, 2007). The presence of four mutations in a Libyan haplotype (CC A65.1) from its Atlantic ancestor haplotype (likely to be CC-A2.1) places the oldest colonisation of the Mediterranean as a pre-Holocenic event occurring ca. 65,000 years ago (20,000-200,000). Thus, regardless of the molecular rate used, $C$. caretta seems to have been present in the Mediterranean before the end of the last glacial period $(\sim 18,000$ years ago; Thunell, 1979). According to this $3 \times$ molecular rate, turtles could have survived several cold periods in the Mediterranean (Cacho et al., 


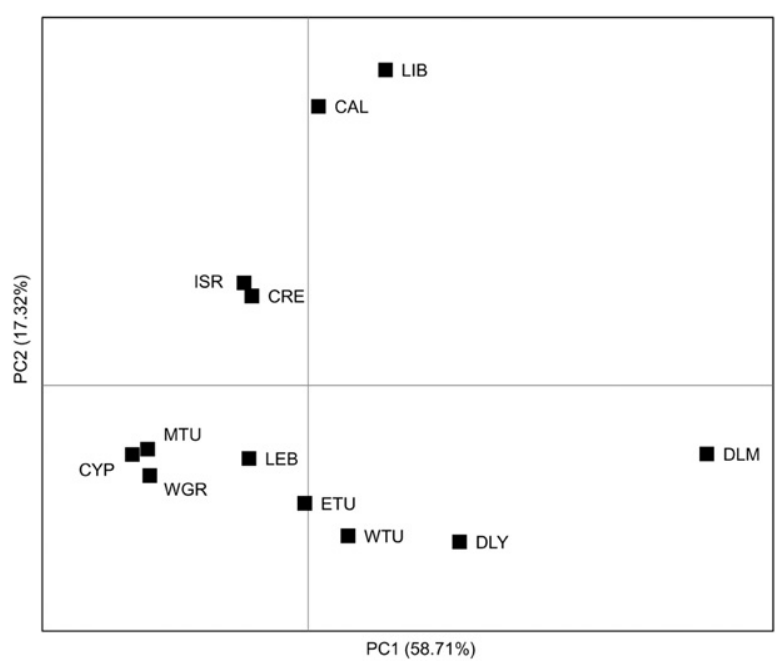

Fig. 3. Principal Coordinate Analysis for pairwise genetic distances $\left(\gamma_{\mathrm{st}}\right)$ between nesting colonies in the Mediterranean. First two Principal Coordinates (PC1 and PC2) and the percentage of variation explained by the 2 axes included.

2000). The nesting grounds in Western Greece also present a haplotype (CC-A32.1) that is separated from its Atlantic ancestor by two changes, indicating that the population in that area has been stable for a long period of time. The presence of this haplotype dates the colonisation of Western Greece at ca. 30,000 years ago $(10,000-100,000)$. This might also be true for Eastern Turkey, as haplotypes CC-A3.2 and CC-A52.1 are also separated by two mutations from the Atlantic ancestor, if it is CC-A2.1, or by one mutation if CC-A3.1 was already present in the colonisers. In the latter, the colonisation of Eastern Turkey would be more recent, 15,000 years ago (5000-50,000), but discriminating between these two scenarios is dependent of future long sequences analyses of individuals from the Western Atlantic rookeries. The possible pre-Holocenic colonisation was not suggested by Bowen et al. (1993a) because they only considered palaeoclimatic evidence for a more restricted genetic sampling area. Thus, the presence of cold temperatures off Greece 18-12 kya, which could not have allowed nesting success on its beaches, brought Bowen et al. (1993a) to hypothesise a much more recent colonisation. However, the analysis of genetic markers locates this origin earlier than previously thought, suggesting that loggerhead turtles colonised the Mediterranean ca. 65,000 years ago $(20,000-200,000)$ and that might have survived glacial periods by nesting at least in Libya and perhaps in Western Greece and Eastern Turkey as well. Thus, the first colonisation event would have happened during the upper Pleistocene and hence before the last glacial maximum.

The star-like shape of the haplotype network is a strong indication of recent expansions such as those related to post-glacial colonisation events (Kaiser et al., 2010; Maggs et al., 2008). This is corroborated by the global Fu's Fs although signal of expansion was only found significant for Eastern Turkey. Furthermore, as geographic and genetic distances were uncorrelated both when using Lat/Long positions and minimum coastal distances, we can discard isolation by distance as an explanation for the overall differentiation pattern. The higher diversity and haplotype divergences found in Libya (Saied et al., 2012; this study), and to a lesser extent in Western Greece and Eastern Turkey, suggest that these three areas could have acted as refugia during cold events maintaining stable population sizes with mild or null bottlenecks. The glacial phase that affected the area from ca. 120 to 20 kya (Woodward and Hughes, 2011) probably caused the extinction of most of the populations in the basin leading to the disappearance of some ancestral haplotypes. However, some populations present in the warmer parts of Northern Africa would have survived during these glacial events. During the ensuing interglacial periods, loggerhead turtles might have recolonised the Eastern Mediterranean, only to become extinct in most of the new nesting

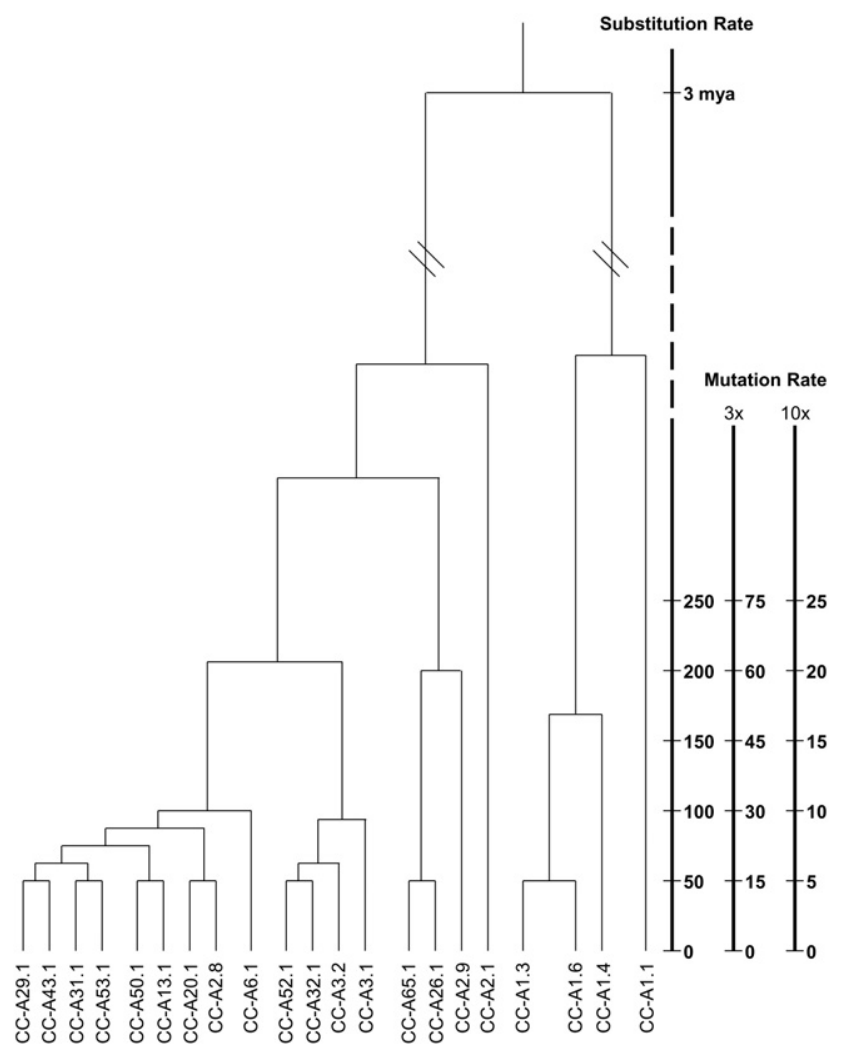

Fig. 4. Haplotype tree adapted from the Bayesian relaxed-clock model results inferred by beast. Time bars show different estimated dates (kya) for haplotype coalescence under a substitution rate of $\sim 0.8 \% \mathrm{My}^{-1}$ (left) and mutation rates 3 and 10 times faster (centre and right, respectively) following Emerson (2007).

grounds with the last glacial maximum. Nevertheless, the presence of haplotype CC-A6.1 in Western Greece and haplotypes CC-A3.2 and CC-A52.1 in Eastern Turkey indicates that these populations might have survived at least the most recent glacial peak. Consequently, the northern part of the Eastern Mediterranean and Western Peloponnese seems to have acted as warm refugia for marine species at that time, as has already been suggested for fishes (Domingues et al., 2008). This hypothesis could explain the genetic structure currently seen in Turkey, with a strong westward decline in haplotype diversity and a high variability in the frequency of CC-A3.1 between adjoining sites.

The existence of the highest frequencies of unique haplotypes in Libya and Eastern Turkey suggests that Western Greece probably was less suitable than the Libyan and Turkish coasts as a refugium. This may be explained by Libya and Eastern Turkey presenting a wider continental shelf which allowed a gentle progression of nesting beaches when the sea level decreased during glacial periods (Patarnello et al., 2007). Conversely, off the coast of Greece (Peloponnese), the continental shelf is much narrower which resulted in major redistribution of beaches and loss of many suitable nesting sites due to sea level fluctuations. This can be corroborated by the results found in our study, showing a strong correlation between the nucleotide diversity, width of the continental shelf and sea surface temperature in each of these refugia. Thus, the presence of warmer temperatures and wider continental shelves off Libya and Eastern Turkey could explain the high genetic variability found in these two areas. According to this correlation, Egypt could also be a potential refugium, but its population was depleted during the first half of the 20th century due to direct exploitation (Nada and Casale, 2010; Sella, 1982). It is worth noting that currently, the largest rookeries in the Mediterranean are found at these potential refugia (Libya, Turkey and Western Greece; Fig. 1). However, this could be an artefact since population sizes in the easternmost 
Mediterranean rookeries (Israel and Lebanon) have notably changed in the past centuries due to human impacts such as fishing, direct exploitation and beach excavations (Sella, 1982).

The evolutionary hypothesis presented above is in accordance with previous studies suggesting that populations of several species of marine turtles survived glacial periods in warm refugia worldwide. Reece et al. (2005) found that Mexico, South Florida and the Caribbean may have acted as Pleistocenic refugia for Western Atlantic populations of loggerhead turtles during the climate depression at the PliocenePleistocene border. Green (Chelonia mydas) and hawksbill (Eretmochelys imbricata) turtles also suffered some population contractions (Reece et al., 2005) and equatorial regions such as Brazil and Guinea Bissau have been proposed as Pleistocenic refugia for Atlantic green turtles (Encalada et al., 1996). Of all sea turtle species, the leatherback turtle (Dermochelys coriacea) may have been the most deeply affected by climate fluctuations, since it is the only species that extensively feeds at high latitudes (James and Mrosovsky, 2004). Nonetheless, it has been suggested that leatherbacks might have survived in the Indian-Pacific during the early Pleistocene to later recolonise the Atlantic, with a subsequent genetic bottleneck (Dutton et al., 1999).

Currently, loggerhead turtles from the Atlantic rookeries abound in the Western Mediterranean (Carreras et al., 2006), where sea surface temperatures are high enough to allow them to forage year round (Revelles et al., 2007a). Some Atlantic individuals even venture into the Eastern Mediterranean, but they are scarce there (Carreras et al., 2006; Casale et al., 2008; Maffucci et al., 2006). Young loggerheads from the Atlantic rookeries reach Western Europe after drifting passively in the Gulf Stream and some may spend several years in the Mediterranean before returning to the Atlantic (Revelles et al., 2007b). This process certainly operated during the Pleistocene and allowed loggerheads to colonise the Mediterranean. However, during the cold phases of the Pleistocene, the sea surface temperature in the Western Mediterranean might have been too low (Thiede, 1978) to allow loggerheads to use it even as a foraging ground. This means that any gene flow between the Atlantic and the Mediterranean populations, mediated by dispersal of turtles from the Atlantic populations, was interrupted during the cold phases of the Pleistocene thus leading to an increased genetic differentiation between the Mediterranean and Atlantic populations. The gene flow and the colonisation events were probably restored in the following warm phase when the Western Mediterranean again became a suitable feeding ground for Atlantic loggerheads. However, contemporary gene flow rates appear to be insufficient to genetically homogenise the two areas (Carreras et al., 2011).

The presence of haplotype CC-A20.1 in Calabria could be homoplasic, as previously discussed, but may also reveal a new colonisation event from the Atlantic that occurred during the Holocene. This could explain why this Atlantic haplotype is found exclusively in the most regularly visited westernmost nesting site in the Mediterranean. If this hypothesis is true, the current genetic structure of loggerhead turtles in the Mediterranean would be the result of at least two independent colonisation events. One taking place ca. 65,000 years ago $(20,000-200,000)$ and a recent one 15,000 years ago (5000-50,000) combined with local extinction and re-colonisation through the expansion of individuals from a few refugia following climatic fluctuations.

\subsection{Conservation implications}

Loggerhead turtles nesting in the Mediterranean are considered an independent regional management unit (Wallace et al., 2010) with highly reduced gene flow with other populations in the North Atlantic (Carreras et al., 2011). The rookeries within this regional management unit generally exhibit stable abundance with high genetic diversity. However, under a relatively high degree of threat due to human activities, these populations could decline in the future if threats are not abated (Wallace et al., 2011). The main human activities impacting loggerhead turtles in the region are incidental bycatch and beach loss due to tourism development. Furthermore, direct take of immatures and adults is still a problem in some countries (Casale and Margaritoulis, 2010). Although the impact of these activities should be reduced everywhere, careful planning is necessary to guarantee that the conservation actions have positive impacts on the target populations. For instance, reducing the high levels of bycatch by bottom trawlers operating in the Adriatic sea (Casale et al., 2004) or off Tunisia (Casale et al., 2008) will certainly benefit the Mediterranean management unit. However, the actual relevance of such a hypothetical reduction for each of the four major groups of rookeries in the region (Libya, Dalaman and Dalyan, Calabria and the rest of the rookeries) could only partially be anticipated with the data previously available (Casale et al., 2008; Maffucci et al., 2006). The data presented here will dramatically improve the resolution of mixed stock analysis (Carreras et al., 2006; Saied et al., 2012) for feeding grounds and hence will allow conservationists to indentify which rookeries will most likely benefit from reducing bycatch at particular feeding grounds or with a particular type of fishing gear.

The consequences of global warming are also a matter of concern, as direct impacts on marine turtles come from the flooding of nesting beaches due to the rise in sea level (Baker et al., 2006) and altered sex ratios because of the temperature-dependent sexual determination of these species (Hawkes et al., 2009). Marine turtles have adapted to previous climate fluctuations (Dutton et al., 1999; Encalada et al., 1996; Reece et al., 2005; this study), but they will have much lower chances in the context of the highly human-modified Mediterranean Sea. As temperature increases, some loggerhead populations are expected to expand northwards, colonising areas currently too cold for reproduction. However, most of the coastline in the northern shore of the Mediterranean has been intensely developed by the tourism industry and few places remain suitable for the nesting of loggerhead turtles. Furthermore, total beach surface will decrease as the sea level rises and buildings, roads and other infrastructures impede beaches moving inland. In this context, competition between the tourism industry and nesting loggerhead turtles will increase, with uncertain results for loggerhead turtles.

\section{Acknowledgements}

We are thankful to all the researchers, assistants and volunteers who collaborated in sample collection. This study was co-funded by projects CGL2009-10017 and CTM2010-22218 of the Spanish Government (CICYT) and partially funded by the EU project Protección de Praderas de Posidonia en LICs de Baleares LIFE00NAT/E/7303 and Zoo de Barcelona. Marcel Clusa was supported by the Biodiversity Research Institute (IRBio) of the University of Barcelona and all the IRBio authors are part of the research groups 2009SGR-842 and 2009SGR-636 of the Generalitat de Catalunya. D.M. and A.F.R. thank the ARCHELON field leaders Sonja Baker, Christina Davy and Sandra Müller for their help in sample collection. We thank Gregg Ashcroft for English grammar corrections. [RH]

\section{References}

Abreu-Grobois, A., Horrocks, J., Formia, A., Dutton, P., LeRoux, R., Vélez-Zuazo, X., Soares, L., Meylan, P., 2006. New mtDNA dloop primers which work for a variety of marine turtle species may increase the resolution capacity of mixed stock analysis. Proceedings of the 26th Annual Symposium on Sea Turtle Biology and Conservation, p. 179

Alberto, F., Massa, S., Manent, P., Diaz-Almela, E., Arnaud-Haond, S., Duarte, C.M., Serrão, E.A. 2008. Genetic differentiation and secondary contact zone in the seagrass Cymodoced nodosa across the Mediterranean-Atlantic transition region. J. Biogeogr. 35, 1279-1294.

Almada, V.C., Oliveira, R.F., Gonçalves, E.J., Almeida, A.J., Santos, R.S., Wirtz, P., 2001. Patterns of diversity of the north-Eastern Atlantic bleniid fish fauna (Pisces: Blenniidae) Glob. Ecol. Biogeogr. 10, 411-422.

Arnaud-Haond, S., Migliaccio, M., Diaz-Almela, E., Teixeira, S., van de Vliet, M.S. Alberto, F., Procaccini, G., Duarte, C.M., Serrão, E.A., 2007. Vicariance patterns in the Mediterranean Sea: east-west cleavage and low dispersal in the endemic seagrass Posidonia oceanica. J. Biogeogr. 34, 963-976. 
Avise, J.C., Bowen, B.W., Lamb, T., Meylan, A.B., Bermingham, E., 1992. Mitochondria DNA evolution at a turtle's pace: evidence for low genetic variability and reduced microevolutionary rate in the testudines. Mol. Biol. Evol. 9, 457-473.

Bahri-Sfar, L., Lemaire, C., Ben Hassine, O.K., Bonhomme, F., 2000. Fragmentation and sea bass populations in the Western and Eastern Mediterranean as revealed by microsatellite polymorphism. Proc. R. Soc. B 267, 929-935.

Baker, J.D., Littnan, C.L., Johnston, D.W., 2006. Potential effects of sea level rise on the terrestrial habitats of endangered and endemic megafauna in the NorthWestern Hawaiian Islands. Endanger. Species Res. 2, 21-30.

Bandelt, H.J., Forster, P., Rohl, A., 1999. Median-joining networks for inferring intraspecific phylogenies. Mol. Biol. Evol. 16, 37-48.

Bowen, B.W., 2003. What is a loggerhead turtle? The genetic perspective. In: Bolten, A.B., Witherington, B.E. (Eds.), Loggerhead Sea Turtle. Smithsonian Books, Washington, pp. 7-27.

Bowen, B.W., Karl, A., 2007. Population genetics and phylogeography of sea turtles Mol. Ecol. 16, 4886-4907.

Bowen, B.W., Avise, J.C., Richardson, J.I., Meylan, A.B., Margaritoulis, D., Hopkins-Murphy, S.R., 1993a. Population structure of loggerhead turtles (Caretta caretta) in the NorthWestern Atlantic Ocean and Mediterranean Sea. Conserv. Biol. 7, 834-844.

Bowen, B.W., Nelson, W.S., Avise, J.C., 1993b. A molecular phylogeny for marine turtles: trait mapping, rate assessment and conservation relevance. Proc. Natl. Acad. Sci. 90, 5574-5577.

Bowen, B.W., Bass, A.L., Chow, S., Bostrom, M., Bjorndal, K.A., Bolten, A.B., Okuyama, T., Bolker, B.M., Epperly, S., LaCasella, E., Shaver, D., Dodd, M., Hopkinsmurphy, S.R., Musick, J.A., Swingle, M., Rankin-Baransky, K., Teas, W., Witzell, W.N., Dutton, P.H., 2004. Natal homing in juvenile loggerhead turtles (Caretta caretta). Mol. Ecol. 13, 3797-3808.

Cacho, I., Grimalt, J.O., Sierro, F.J., Shackleton, N., Canals, M., 2000. Evidence for enhanced Mediterranean thermohaline circulation during rapid climatic coolings. Earth Planet. Sci. Lett. 183, 417-429.

Carr, A., Ogren, L., 1960. The ecology and migrations of sea turtles, 4. Bull. Am. Mus. Nat Hist. 121, 1-48.

Carreras, C., Pont, S., Maffucci, F., Pascual, M., Barceló, A., Bentivegna, F., Cardona, L Alegre, F., SanFélix, M., Fernández, G., Aguilar, A., 2006. Genetic structuring of immature loggerhead sea turtles (Caretta caretta) in the Mediterranean Sea reflects water circulation patterns. Mar. Biol. 149, 1269-1279.

Carreras, C., Pascual, M., Cardona, L., Aguilar, A., Margaritoulis, D., Rees, A.F., Turkozan, O. Levy, Y., Gasith, A., Aureggi, M., Khalil, M., 2007. The genetic structure of the loggerhead sea turtle (Caretta caretta) in the Mediterranean as revealed by nuclear and mitochondrial DNA and its conservation implications. Conserv. Genet. 8, 761-775.

Carreras, C., Pascual, M., Cardona, L., Marco, A., Bellido, J.J., Castillo, J.J., Tomás, J., Raga, J.A., SanFélix, M., Fernández, G., Aguilar, A., 2011. Living together but remaining apart: Atlantic and Mediterranean loggerhead sea turtles (Caretta caretta) in shared feeding grounds. J. Hered. 102, 666-677.

Casale, P., Margaritoulis, D., 2010. Sea turtles in the Mediterranean: Distribution, Threats and Conservation Priorities. IUCN, Gland, Switzerland.

Casale, P., Laurent, L., De Metrio, G., 2004. Incidental capture of marine turtles by the Italian trawl fishery in the north Adriatic Sea. Biol. Conserv. 119, 287-295.

Casale, P., Freggi, D., Gratton, P., Argano, R., Oliverio, M., 2008. Mitochondrial DNA reveals regional and interregional importance of the central Mediterranean African shelf for loggerhead sea turtles (Caretta caretta). Sci. Mar. 72, 541-548.

Chaieb, O., El Ouaer, A., Maffucci, F., Bradai, M.N., Bentivegna, F., Said, K., Chatti, N., 2010. Genetic survey of loggerhead turtle Caretta caretta nesting population in Tunisia. Mar. Biodivers. Rec. 3, e20.

Crandall, K.A., Bininda-Emonds, O.R.P., Mace, G.M., Wayne, R.K., 2000. Considering evolutionary processes in conservation biology. Tree 15, 290-295.

Crandall, K.A., Sbrocco, E.J., DeBoer, T.S., Barber, P.H., Carpenter, K.E., 2012. Expansion dating: calibrating molecular clocks in marine species from expansions onto the sunda shelf following the last glacial maximum. Mol. Biol. Evol. 29, 707-719.

Domingues, V.S., Santos, R.S., Brito, A., Alexandrou, M., Almada, V.C., 2007. Mitochondria and nuclear markers reveal isolation by distance and effects of Pleistocene glaciation in the northEastern Atlantic and Mediterranean populations of the white seabream (Diplodus sargus, L.). J. Exp. Mar. Biol. Ecol. 346, 102-113.

Domingues, V.S., Alexandrou, M., Almada, V.C., Robertson, D.R., Brito, A., Santos, R.S. Bernardi, G., 2008. Tropical fishes in a temperate sea: evolution of the wrasse Thalassoma pavo and the parrotfish Sparisoma cretense in the Mediterranean and the adjacent Macaronesian and Cape Verde archipelagos. Mar. Biol. 154, 465-474.

Drummond, A.J., Rambaut, A., 2007. BEAST: Bayesian evolutionary analysis by sampling trees. BMC Evol. Biol. 7, 1-8.

Dutton, P.H., 1995. Methods for collection and preservation of samples for sea turtle genetic studies. In: Bowen, B.W., Witzell, W.N. (Eds.), Proceedings of the International Symposium on Sea Turtle Conservation Genetics. NOAA Technical Memorandum NMFS-SEFSC 396. National Technical Information Service, Springfield, Virginia, pp. 17-24.

Dutton, P.H., Davis, S.K., Guerra, T., Owens, D., 1996. Molecular phylogeny for marine turtles based on sequences of the ND4-Leucine tRNA and control regions of mitochondrial DNA. Mol. Phylogenet. Evol. 5, 511-521.

Dutton, P.H. Bowen, B.W. Owens, D.W. Barragan, A. Davis, S.K. 1999. Global phylogeography of the leatherback turtle (Dermochelys coriacea). J. Zool. (Lond) 248, 397-409.

Emerson, B.C., 2007. Alarm bells for the molecular clock? No support for Ho et al.'s model of time-dependent molecular rate estimates. Syst. Biol. 56, 345-355.

Encalada, S.E., Lahanas, P.N., Bjorndal, K.A., Bolten, A.B., Miyamoto, M.M., Bowen, B.W., 1996. Phylogeography and population structure of the Atlantic and Mediterranean green turtle Chelonia mydas: a mitochondrial DNA control region sequence assessment. Mol. Ecol. 5, 473-483.
Encalada, S.E., Bjorndal, K.A., Bolten, A.B., Zurita, J.C., Schroeder, B., Possardt, E., Sears, C.J., Bowen, B.W., 1998. Population structure of loggerhead turtle (Caretta caretta) nesting colonies in the Atlantic and Mediterranean as inferred from mitochondrial DNA control region sequences. Mar. Biol. 130, 567-575.

ESRI, 2011. ArcGIS Desktop: Release 10. Environmental Systems Research Institute, Redlands, California.

Excoffier, L., Laval, L.G., Schneider, S., 2005. Arlequin (version 3.0): an integrated software package for population genetics data analysis. Evol. Bioinformatics Online 47-50.

FitzSimmons, N.N., Limpus, C.J., Norman, J.A., Goldizen, A.R., Miller, J.D., Moritz, C., 1997. Philopatry of male marine turtles inferred from mitochondrial DNA markers. Proc. Natl. Acad. Sci. 94, 8912-8917.

Fu, Y.X., 1997. Statistical neutrality of mutations against population growth, hitchhiking and background selection. Genetics 147, 915-925.

Garofalo, L., Mingozzi, T., Micò, A., Novelletto, A., 2009. Loggerhead turtle (Caretta caretta) matrilines in the Mediterranean: further evidence of genetic diversity and connectivity. Mar. Biol. 156, 2085-2095

Grant, W.S., Bowen, B.W., 1998. Shallow population histories in deep evolutionary lineages of marine fishes: insights from sardines and anchovies and lessons for conservation. J. Hered. 89, 415-426.

Haffer, J., 1982. General aspects of the refuge theory. In: Prance, G. (Ed.), Biological Diversification in the Tropics. Columbia University Press, New York, pp. 6-24.

Hall, T.A., 1999. BioEdit: a user-friendly biological sequence alignment editor and analysis program for Windows 95/98/NT. Nucleic Acids Symp. Ser. 41, 95-98.

Hawkes, L.A., Broderick, A.C., Godfrey, M.H., Godley, B.J., 2009. Climate change and marine turtles. Endanger. Species Res. 7, 137-154.

Hewitt, G.M., 1996. Some genetic consequences of ice ages, and their role in divergence and speciation. Biol. J. Linn. Soc. 58, 247-276.

Hewitt, G.M., 2000. The genetic legacy of Quaternary ice ages. Nature 405, 907-913. Ho, S.Y.W., Lanfear, R., Bromham, L., Phillips, M.J., Soubrier, J., Rodrigo, A.G., Cooper, A., 2011. Time-dependent rates of molecular evolution. Mol. Ecol. 20, 3087-3101.

Howell, N., Smejkal, C.B., Mackey, D.A., Chinnery, P.F., Turnbull, D.M., Herrnastadt, C., 2003. The pedigree rate of sequence divergence in the human mitochondrial genome: there is a difference between phylogenetic and pedigree rates. Am. J. Hum. Genet. 72, 659-670.

James, M.C., Mrosovsky, N., 2004. Body temperatures of leatherback turtles (Dermochelys coriacea) in temperate waters off Nova Scotia, Canada. Can. J. Zool. 82, 1302-1306.

Kaiser, T.S., Neumann, D., Heckel, D.G., Berendonk, T.U., 2010. Strong genetic differentiation and postglacial origin of populations in the marine midge Clunio marinus (Chironomidae, Diptera). Mol. Ecol. 19, 2845-2857.

Karl, S.A., Toonen, R.J., Grant, W.S., Bowen, B.W., 2012. Common misconceptions in molecular ecology: echoes of the modern synthesis. Mol. Ecol. http://dx.doi.org/ 10.1111/j.1365-294X.2012.05576.x.

Lambert, D.M., Ritchie, P.A., Millar, C.D., Holland, B., Drummond, A.J., Baroni, C., 2002. Rates of evolution in ancient DNA from Adélie penguins. Science 295, 2270-2273.

Laurent, L., Lescure, J., Excoffier, L., Bowen, B., Domingo, M., Hadjichristophorou, M., Kornaraky, L., Trabuchet, G., 1993. Genetic studies of relationships between Mediterranean and Atlantic populations of loggerhead Caretta caretta with a mitochondrial marker. C. R. Acad. Sci. 316, 1233-1239.

Laurent, L., Casale, P., Bradai, M.N., Godley, B.J., Gerosa, G., Broderick, A.C., Schroth, W., Schierwater, B., Levy, A.M., Freggi, D., Abd El-Mawla, E.M., Hadoud, D.A., Gomati, H.E., Domingo, M., Hadjichristophorou, M., Kornaraky, L., Demirayak, F., Gautier, C.H., 1998. Molecular resolution of marine turtle stock composition in fishery bycatch: a case study in the Mediterranean. Mol. Ecol. 7, 1529-1542.

Lee, P.L.M., 2008. Molecular ecology of marine turtles: new approaches and future directions. J. Exp. Mar. Biol. Ecol. 356, 25-42.

Lessios, H.A., 2008. The great american schism: divergence of marine organisms after the rise of the central american isthmus. Annu. Rev. Ecol. Evol. Syst. 39, 63-91.

Librado, P., Rozas, J., 2009. DnaSP v5: a software for comprehensive analysis of DNA polymorphism data. Bioinformatics 25, 1451-1452.

Maffucci, F., Kooistra, W.H.C.F., Bentivegna, F., 2006. Natal origin of loggerhead turtles, Caretta caretta, in the neritic habitat off the Italian coasts, Central Mediterranean. Biol. Conserv, 127, 183-189.

Maggs, C.A., Castilho, R., Foltz, D., Henzler, C., Jolly, M.T., Kelly, J., Olsen, J., Perez, K.E., Stam, W., Väinöla, R., Viard, F., Wares, J., 2008. Evaluating signatures of glacial refugia for North Atlantic benthic marine taxa. Ecology 89, S108-S122.

Magoulas, A., Tsimenides, N., Zouros, E., 1996. Mitochondiral DNA phylogeny and the reconstruction of the population history of a species: the case of the European anchovy (Engraulis encrasicolus). Mol. Biol. Evol. 13, 178-190.

Manni, F. Guérard, E., Heyer, E. 2004. Geographic patterns of (genetic, morphologic, linguistic) variation: how barriers can be detected by "Monmonier's algorithm". Hum. Biol. 76, 173-190.

Margaritoulis, D., 1998. Interchange of nesting loggerheads among Greek beaches. Proceedings of the Seventeenth Annual Sea Turtle Symposium, pp. 239-241.

Margaritoulis, D., Argano, R., Baran, I., Bentivegna, F., Bradai, M.N., Camiñas, J.A., Casale, P., De Metrio, G., Demetropoulos, A., Gerosa, G., Godley, B.J., Haddoud, D.A. Houghton, J., Laurent, L. Lazar, B., 2003. Loggerhead turtles in the Mediterranean Sea: present knowledge and conservation perspectives. In: Bolten, A.B., Witherington, B.E. (Eds.), Loggerhead Sea Turtle. Smithsonian Books, Washington, pp. 175-198.

Meylan, A.B., Bowen, B.W., Avise, J.C., 1990. A genetic test of the natal homing versus social facilitation models for green turtle migrations. Science 248, 724-727.

Miller, J.D., Limpus, C.L., Godfrey, M.H., 2003. Nest site selection through hatchling emergence. In: Bolten, A.B., Witherington, B.E. (Eds.), Loggerhead Sea Turtle. Smithsonian Books, Washington, pp. 125-143. 
Monzón-Argüello, C., Rico, C., Naro-Maciel, E., Varo-Cruz, N., López, P., Marco, A., LópezJurado, L.F., 2010. Population structure and conservation implications for the loggerhead sea turtle of the Cape Verde Islands. Conserv. Genet. 11, 1871-1884.

Moritz, C., 1994. Applications of mitochondrial DNA analysis in conservation: a critical review. Mol. Ecol. 3, 401-411.

Nada, M., Casale, P., 2010. Egypt. In: Casale, P., Margaritoulis, D. (Eds.), Sea Turtles in the Mediterranean: Distribution, Threats and Conservation Priorities. IUCN, Gland, Switzerland, pp. 65-76.

Narum, S.R., 2006. Beyond Bonferroni: less conservative analyses for conservation genetics. Conserv. Genet. 7, 783-787.

Nei, M., 1987. Molecular Evolutionary Genetics. Columbia University Press, Oxford, New York.

Norman, J.A., Moritz, C., Limpus, C.J., 1994. Mitochondrial DNA control region polymorphisms: genetic markers for ecological studies of marine turtles. Mol. Ecol. 3, 363-373.

Patarnello, T., Volckaert, F.A.M.J., Castilho, R., 2007. Pillars of Hercules: in the AtlanticMediterranean transition a phylogeographical break? Mol. Ecol. 16, 4426-4444.

Peakall, R., Smouse, P.E., 2006. GENALEX 6: genetic analysis in Excel. Population genetic software for teaching and research. Mol. Ecol. Notes 6, 288-295.

Pérès, J.M., 1985. History of the Mediterranean biota and the colonization of the depths. In: Margalef, R. (Ed.), Western Mediterranean. Key Environments. Pergamon Press, Oxford, pp. 198-232.

Reece, J.S., Castoe, T.A., Parkinson, C.L., 2005. Historical perspectives on population genetics and conservation of three marine turtle species. Conserv. Genet. 6, 235-251.

Revelles, M., Cardona, L., Aguilar, A., San Félix, M., Fernández, G., 2007a. Habitat use by immature loggerhead turtles in the Algerian basin (Western Mediterranean): swimming behaviour, seasonality and dispersal pattern. Mar. Biol. 151, 1501-1515.

Revelles, M., Carreras, C., Cardona, L., Marco, A., Bentivegna, F., Castillo, J.J., de Martino, G., Mons, J.L., Smith, M.B., Rico, C., Pascual, M., Aguilar, A., 2007b. Evidence for an asymmetrical size exchange of loggerhead sea turtles between the Mediterranean and the Atlantic through the Straits of Gibraltar. J. Exp. Mar. Biol. Ecol. 349, 261-271.

Rousset, F., 2008. GENEPOP'007: a complete re-implementation of the GENEPOP software for Windows and Linux. Mol. Ecol. Resour. 8, 103-106.

Saied, A., Maffucci, F., Hochscheid, S., Dryag, S., Swayeb, B., Borra, M., Oureghi, A., Procaccini, G., Bentivegna, F., 2012. Loggerhead turtles nesting in Libya: an important management unit for the Mediterranean stock. Mar. Ecol. Prog. Ser. 450, 207-218.
Sella, I., 1982. Sea turtles in the Eastern Mediterranean and northern Red Sea. In: Bjorndal, K.A. (Ed.), Biology and Conservation of Sea Turtles. Smithsonian Institution Press, Washington, pp. 417-423.

Shamblin, B.M., Dodd, M.G., Bagley, D.A., Ehrhart, L.M., Tucker, A.D., Johnson, C., Carthy, R.R., Scarpino, R.A., McMichael, E., Addison, D.S., Williams, K.L., Frick, M.G., Ouellette, S., Meylan, A.B., Godfrey, M.H., Murphy, S.R., Nairn, C.J., 2011. Genetic structure of the southEastern United States loggerhead turtle nesting aggregation: evidence of additional structure within the peninsular Florida recovery unit. Mar. Biol. 158, 571-587.

SPSS Inc., 2006. SPSS 15.0 for Windows User's Guide. SPSS Inc., Chicago.

Taberlet, P., Fumagalli, L., Wust-Saucy, A.G., Cosson, J.F., 1998. Comparative phylogeography and postglacial colonization routes in Europe. Mol. Ecol. 7, 453-464.

Thiede, J., 1978. A glacial Mediterranean. Nature 276, 680-683.

Thunell, R.C., 1979. Eastern Mediterranean sea during the last glacial maximum; an 18,000-years B.P. reconstruction. Quat. Res. 11, 353-372.

Wallace, B.P., DiMatteo, A.D., Hurley, B.J., Finkbeiner, E.M., Bolten, A.B., et al., 2010 Regional Management Units for marine turtles: a novel framework for prioritizing conservation and research across multiple scales. PLoS One 5, e15465 http:// dx.doi.org/10.1371/journal.pone.0015465.

Wallace, B.P., DiMatteo, A.D., Bolten, A.B., Chaloupka, M.Y., Hutchinson, B.J., et al., 2011 Global conservation priorities for marine turtles. PLoS One 6, e24510 http:// dx.doi.org/10.1371/journal.pone.0024510.

Wilson, A.B., Eigenmann Veraguth, I., 2010. The impact of Pleistocene glaciation across the range of a widespread European coastal species. Mol. Ecol. 19, 4535-4553.

Woodward, J.C., Hughes, P.D., 2011. Glaciation in Greece: a new record of cold stage environments in the Mediterranean. In: Ehlers, J., Gibbard, P.L., Hughes, P.D. (Eds.), Quaternary Glaciations - Extent and Chronology: A Closer Look, Oxford, pp. 175-198.

Yilmaz, C., Turkozan, O., Bardakci, F., 2011. Genetic structure of loggerhead turtle (Caretto caretta) populations in Turkey. Biochem. Syst. Ecol. 39, 266-276.

Zar, J.H., 1984. Biostatistical Analysis. Prentice-Hall, New Jersey. 